\title{
PENDIDIKAN SEKS BAGI MAHASISWA SEBAGAI UPAYA PENCEGAHAN PERILAKU SEKS BEBAS
}

\author{
Dian Utami Ikhwaningrum*, Tikka Dessy Harsanti \\ dianutami90.du@gmail.com \\ Jurusan Pendidikan Pancasila dan Kewarganegaraan, Fakultas Keguruan dan IImu Pendidikan, Universitas \\ Wisnuwardhana Malang \\ Diterima 11 Maret 2020, dipublikasikan 31 Oktober 2020
}

\begin{abstract}
Abstrak
Masa remaja merupakan masa yang banyak akan rasa ingin tahu terhadap segala hal, menyukai petualangan dan tantangan tanpa didahului oleh pertimbangan yang matang termasuk salah satunya masalah seksual. Karena rasa ingin tahu yang tinggi banyak remaja melakukan perilaku seks diluar nikah yang akibatnya banyak mahasiswa yang mengandung dan memiliki anak. Sehingga kehidupan mereka sebagai seorang mahasiswa yang mempunyai kewajiban yaitu belajar dan masuk perkuliahan menjadi terbengkalai. Banyak mahasiswa yang akhirnya tidak dapat melanjutkan perkuliahan karena harus kembali ke daerahnya untuk merawat, menafkahi anaknya. serta mereka harus cuti kuliah karena mengandung dan melahirkan serta sampai ada yang mengalami kehamilan beresiko karena kurangnya informasi tentang kehamilan. Dari berbagai permasalahan tersebut, maka ditindaklanjuti dengan melaksanakan kegiatan sosialisasi mengenai pendidikan seks bagi mahasiswa sebagai upaya pencegahan perilaku seks bebas. Metode yang digunakan pada program ini, yaitu metode survey sasaran, persiapan sarana dan prasarana, pelaksanaan kegiatan, dan evaluasi kegiatan. Tujuan dari pengabdian ini adalah mahasiswa memperoleh ilmu dan pengetahuan tentang seks, dampak dan bahaya yang terjadi akibat seks bebas bagi kesehatan, psikologis dan kehidupan sosial mereka kedepan.
\end{abstract}

Kata Kunci: Pendidikan Seks, Seks Bebas

\section{PENDAHULUAN}

Masa remaja adalah peralihan dari masa anak ke masa dewasa yang mengalami perkembangan semua aspek atau fungsi untuk memasuki masa dewasa (Saputro, 2018). Pada masa remaja terjadi perubahan baik secara fisik dan lingkungan seperti perkembangan fungsi-fungsi tubuh, pada tahap ini alat reproduksi mulai berfungsi, libido mulai tumbuh, emosi cenderung labil, perubahan intelektual, dan perubahan moral. Remaja dalam hal ini mahasiswa yang sebagian besar berasal dari luar kota yang jauh dari orang tua dan keluarga dengan mudah dapat melakukan hal-hal yang ingin diketahuinya terutama terkait dengan seks karena kemudahaan atas ketersediaan sarana di sekitarnya yang dapat memenuhi keingintahuan tersebut. Dimana orang tua dan keluarga menjadi lingkungan yang memiliki usaha preventif paling kuat dalam menjaga para remaja terlibat dalam aktifitas pergaulan bebas (Wiradimadja, 2020).

Pada awalnya, ketertarikan remaja terhadap seksualitas bersifat self-centered, yaitu fokus pada perubahan-perubahan yang terjadi pada dirinya. Kemudian, secara bertahap remaja mulai tertarik dengan lawan jenis maupun sesama jenis. Bentuk dari perilaku seksual ini bermacammacam, dari berkencan, bercumbu, berpegangan tangan dengan lawan jenis, berpelukan, rangkulan, berciuman sampai melakukan hubungan seksual diluar nikah. Penyebab perilaku seks diluar nikah senada dengan (Prasasti, 2017; Purnama, 2020; Suryoputro et al., 2006) antara lain pengaruh sosial media dengan tayangan-tayangan yang menjurus ke hal yang mengarah ke perilaku seks, mudahnya dalam mengakses video video berkonten pornografi serta tidak ada pengawasan dari orang tua, dan juga pendidikan seks dari orang tua sejak dini karena masih dianggap tabuh untuk diinformasikan dan diajarkan ke anak (Setya, 2019), serta pendidikan agama yang kurang karena usia 
remaja adalah usia masih mencari jati diri dimana ilmu tentang agama masih belum banyak yang mereka pahami

Perkembangan jaman saat ini, ikut mempengaruhi perilaku seksual dalam berpacaran remaja. Hal ini misalnya dapat dilihat bahwa hal-hal yang ditabukan oleh remaja pada beberapa tahun yang lalu, seperti berciuman dan bercumbu kini telah dibenarkan oleh remaja sekarang. Bahkan ada sebagian kecil dari mereka setuju dengan free sex. Kondisi tersebut cukup mengkhawatirkan mengingat perilaku tersebut dapat menyebabkan Kasus Kehamilan Tidak Diinginkan (KTD) yang selanjutnya memicu praktik aborsi yang tidak aman, penularan PMS dan HIV/AIDS, bahkan kematian (Bertens, 2002; Saifulloh, 2011; Zalbawi, 2002). Perilaku seks diluar nikah yang dilakukan mahasiswa berakibat kehamilan, yang berdampak pada kehidupan mereka sebagai seorang mahasiswa. Mahasiswa yang mempunyai kewajiban yaitu datang untuk mengikuti perkuliahan dan belajar menjadi terbengkalai, mereka memilih untuk cuti dan tidak melanjutkan perkuliahan karena harus merawat anaknya dan kembali ke kampung halamanya.

Perilaku seks diluar nikah tersebut mengakibatkan peningkatan kerentanan remaja terhadap berbagai macam penyakit, terutama yang berhubungan dengan kesehatan seksual dan reproduksi, termasuk ancaman terhadap HIV/AIDS (Suryoputro et al., 2006). Selain berakibat ke kesehatan dampak perilaku seks di luar nikah yaitu dari sisi psikologis mahasiswa yaitu rasa depresi dan ada perasaan berdosa karena melakukan seks diluar nikah dan hamil, kesulitan untuk mencari pekerjaan dikarenakan harus mengurus anak dan harus bekerja. Pentingnya pendidikan seks pada remaja merupakan salah satu solusi dalam menghadapi permasalahan-permasalahan yang dialami oleh para remaja (mahasiswa) saat ini. Pendidikan seks mengajarkan dan memberi pengertian serta menjelaskan masalah-masalah yang menyangkut seks, naluri dan perkawinan kepada anak semenjak akalnya mulai tumbuh dan siap memahami hal-hal mengenai seks dan perilaku yang tidak bertanggung jawab (Nurlaeli, 2020). Perguruan tinggi sebagai lembaga pendidikan, penting sekali mengoptimalkan bimbingan konseling sebagai wadah perkembangan psikologis mahasiswa sebagai pendampingan dan sosialisasi pendidikan seks bagi mahasiswa agar mereka mengetahui, memahami dampak yang terjadi dari perilaku seks bebas agar mereka dapat lebih berhati-hati dalam bergaul dan berhubungan dengan lawan jenis.

\section{METODE}

Metode yang digunakan pada program ini, yaitu metode survey sasaran, persiapan sarana dan prasarana, pelaksanaan kegiatan, dan evaluasi kegiatan (Mustari \& Rahman, 2012). Tahap survey sasaran diawali dengan survey mahasiswa yang menjadi sasaran program ini. Untuk awal pengabdian ini yang menjadi sasaran program ini adalah mahasiswa semester 1 karena mereka awal berada di lingkungan yang baru, sehingga bisa mempunyai pengetahuan sebagai bekal untuk menjalani kehidupan sebagai mahasiswa rantauan yang jauh dari keluarga, Tahap kedua adalah Tahap Sosialisasi Program Kegiatan, Pelaksanaan kegiatan aksi muatan program yang paling penting dalam program ini adalah memberikan sosialisasi dan pengarahan kepada mahasiswa agar terhindar dari perilaku seks bebas dan hamil di luar nikah dengan menggali informasi terkait pendidikan seks dan seks itu sendiri dari mahasiswa. Selanjutnya, mahasiswa diberikan edukasi mengenai pendidikan seks secara klinis, yaitu perbedaan organ reproduksi laki-laki dan perempuan, bagaimana cara merawat organ intim, perilaku seks yang tidak aman yang menyebabkan penyakit-penyakit kelamin. Pendidikan seks dari sisi psikologisnya yaitu tentang dampak dari seks bebas, dampak yang ditimbulkan dari pernikahan di usia muda.

Pada tahapan evaluasi pada tahap ini yaitu pelaksanaan evaluasi terhadap keefektifan jalannya program sosialisasi yang dilanjutkan pendampingan kepada mahasiswa terhadap kelebihan dan kekurangan dari program yang telah dijalankan. Hal ini akan menjadi pertimbangan bagi program ini agar bermanfaat untuk sekarang dan masa yang akan datang karena membantu memecahkan permasalahan yang dihadapi mitra akan dilakukan sosialisasi dan pendampingan terhadap mahasiswa tidak hanya yang dari semester 1 saja, dan sosialisasi serta pendampingan ini dilakukan dari para tenaga ahli di bidang pendidikan, ilmu sosial dan psikologi. Para ahli di bidang pendidikan, sosial dan 
psikologi akan membangun pendekatan kepada mahasiswa terutama mahasiswa di lingkungan Universitas Wisnuwardhana Malang.

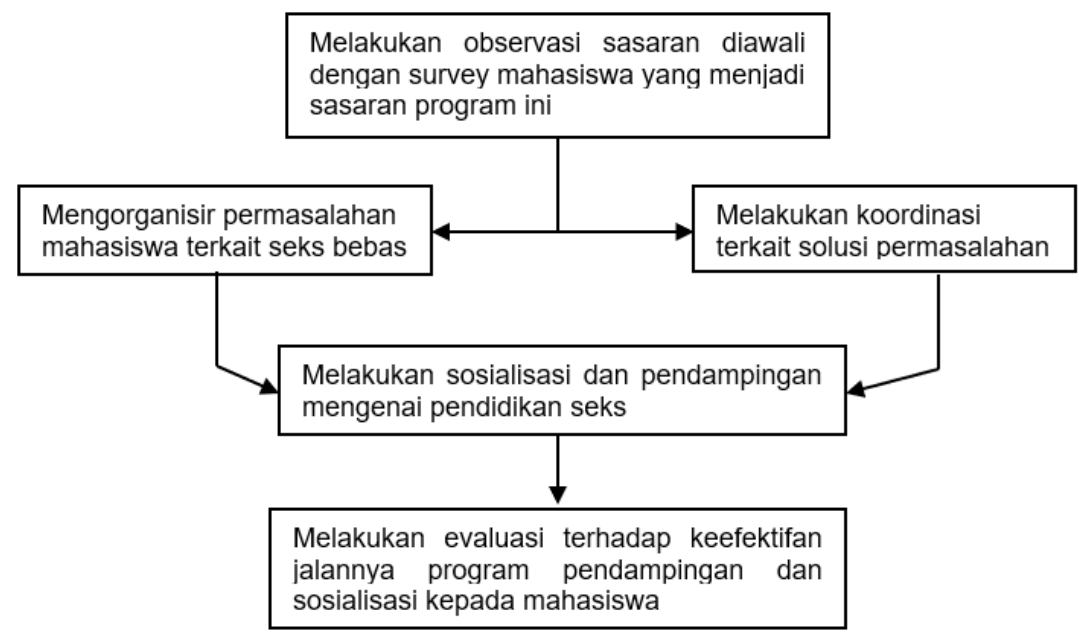

Gambar 1 Tahapan pelaksanaan Pengabdian Kepada Masyarakat

(Sumber: Tim Pengembang)

\section{HASIL DAN PEMBAHASAN}

Berdasarkan hasil kegiatan yang telah dilaksanakan, Kegiatan ini dilaksanakan pada hari Sabtu tanggal 4 Januari 2020 bertempat di Gedung F2 Universitas Wisnuwardhana. Kegiatan ini dihadiri oleh para mahasiswa sejumlah 69 orang. Dapat diketahui bahwa kegiatan ini memberikan dampak positif dan mendapat respon yang baik dan menarik bagi para mahasiswa karena pemahaman mengenai pendidikan seks sangat rendah sekali, mahasiswa memiliki pemahaman yang keliru selama ini mengenai seks.

Kegiatan ini dibagi menjadi 3 sesi, di sesi pertama adalah menggali informasi terkait pendidikan seks dari mahasiswa. Dari sesi pertama ini mahasiswa antusias untuk menyimak dari cerita dan diskusi diketahui bahwa hampir semua mahasiswa tidak tahu mengenai apa itu seks, pendidikan seks, dan pandangan mereka seks serta perbedaan laki-laki dan perempuan secara sosial. Pandangan mahasiswa ketika berdiskusi tentang seks adalah hal yang sangat tabuh dan tidak sesuai dengan norma. Padahal seks itu sendiri dari arti bahasanya adalah jenis kelamin. Dan pendidikan seks dalah pemberian pengetahuan yang benar dan menyiapkannya untuk beradaptasi secara baik dengan sikapsikap seksual.

Pada sesi pertama juga dijelaskan tahap-tahap pendidikan seks sejak dini untuk balita, anakanak, remaja awal dan remaja akhir. Bagaimana mengenai penyebutan alat kelamin yang harus disebut sesuai dengan namanya, tidak boleh di analogikan dengan kata-kata lain. Serta peran orangtua sebagai sarana informasi awal kepada anak dan remaja dimana orang tua dituntut untuk memberikan informasi yang benar dan nyaman terkait seks, agar anak tidak mencari informasi diluar, misal dari internet yang malah akan membuat anak semakin penasaran. Serta sebagai seorang mahasiswa yang jauh dari orangtua dalam menjaga diri agar tidak terjerumus dari seks bebas dan bisa meraih cita-cita.

Menginformasikan juga tentang Perubahan norma dalam Undang-Undang Nomor 1 Tahun 1974 tentang Perkawinan mengenai batas usia untuk melakukan perkawinan, perbaikan norma menjangkau dengan menaikkan batas minimal umur perkawinan bagi wanita. Batas minimal umur perkawinan bagi wanita dipersamakan dengan batas minimal umur perkawinan bagi pria, yaitu 19 (sembilan belas) tahun. Batas usia dimaksud dinilai telah matang jiwa raganya untuk dapat melangsungkan perkawinan agar dapat mewujudkan tujuan perkawinan secara baik tanpa berakhir pada perceraian dan mendapat keturunan yang sehat dan berkualitas.

Sesi kedua adalah mengenai seks secara klinis, yaitu perbedaan organ reproduksi laki-laki dan perempuan, bagaimana cara merawat organ intim, perilaku seks yang tidak aman yang menyebabkan 
penyakit-penyakit kelamin. Pembahasan yang sangat menarik karena mahasiswa selama ini pengetahuan akan alat reproduksinya, fungsi alat reproduksi dan pubertas sangat minim sekali. Bagaimana dalam perawatan alat reproduksi. Dalam sesi ini mahasiswa banyak sekali yang bertanya tentang fungsi dan alat vitalnya dan bagaimana cara merawatnya serta penyakit-penyakit yang mengintai akibat perilaku seks yang tidak aman.

Perbedaan pubertas laki-laki dan perempuan yang ditandai dengan adanya mimpi basah untuk laki-laki dan haid untuk perempuan. Kesehatan reproduksi dalam memfungsikan secara optimal organ reproduksi dan dorongan seksual. Dorongan seksual ada karena keinginan untuk mendapatkan kepuasan secara seksual yang bisa diperoleh dengan perilaku seksual. Hal yang wajar muncul pada karena ketika memasuki usia pubertas, dorongan seksual akan muncul dalam diri seseorang dikarenakan hormon esterogen dan progesteron pada perempuan, serta hormon testosteron pada lakilaki. Tapi hal yang perlu diperhatikan adalah ketika dorongan seksual muncul tidak diimbangi dengan pemahaman terhadap hal-hal yang berkaitan dengan perilaku seksual.

Pada sesi terakhir disampaikan mengenai pendidikan seks dari sisi psikologisnya, tentang dampak dari seks bebas, dampak yang ditimbulkan dari pernikahan di usia muda, mencegah adanya bentuk kekerasan seksual dan pemerkosaan dan adanya penyimpangan seksual yang disebabkan dari salahnya lingkungan pertemanan yang dipilih. Mahasiswa lebih diberikan pemahaman mengenai seks bebas dan akibat-akibat yang ditimbulkan dari seks bebas tersebut, remaja juga diajarkan mengenai membedakan rasa cinta dan nafsu seksual yang dimiliki. Bagaimana perasaan- perasaan berkaitan dengan rasa cinta dan juga nafsu. Bagaimana mengelola nafsu. ketika mereka berpacaran atau terlibat dalam hubungan romantis, hal apa yang boleh dan tidak boleh mereka lakukan.

Proses tumbuh kembang remaja harus mendapat perhatian yang khusus agar fase tersebut dapat terkontrol. Kontrol dan regulasi perlu di lakukan terhadap dorongan-dorongan seks dan implusimplus seks, agar tidak terlampau eksesif dan meledak-ledak, sehingga bisa melemahkan jasmani dan rohani. Remaja harus dapat menghindari pergaulan bebas dan bisa mengontrol dirinya agar memiliki masa depan yang cerah. Sebaliknya mereka yang tak dapat bertahan akan terjerumus pada dunia pergaulan bebas yang kelak akan merusak masa depannya, harapan dan tujuan sebagai genarasi muda akan hancur akibat dari pergaulan bebas yang tidak terkontrol (Pristiwanti \& ilmiah ini berisi tentang Pergaulan, 2013; Tari \& Tafonao, 2019).

Pada masa remaja, pengaruh teman sebaya sangat kuat sehingga munculnya penyimpangan perilaku seksual dikaitkan dengan LGBT, apalagi mahasiswa yang notabene jauh dari pengawasan orangtua dituntut harus cerdas dalam memilih lingkup pertemanan karena dilingkungan sekitar Gay dan Lesbian serta penyimpangan seks sudah menjadi hal yang biasa di kalangan mahasiswa. remaja dengan prestasi rendah dan tahap aspirasi yang rendah cenderung lebih sering memunculkan aktivitas seksual dibandingkan remaja dengan prestasi yang baik di kampusnya.

Mahasiswa ditanamkan moral dan prinsip 'say no' untuk seks pra nikah serta membangun penerimaan terhadap diri sendiri agar mahasiswa dapat membentengi diri dan berani untuk bilang tidak terhadap ajakan ajakan seks bebas, serta pembekalan pada pasangan yang ingin menikah tentang hubungan seks yang sehat dan tepat.

Kegiatan ini sangat menarik bagi mahasiswa karena mereka akhirnya mengetahui tentang pendidikan seks itu bagaimana dan kita menjaga diri, dalam bersosialisasi dan banyak manfaat yang di dapat terhadap perkembangan diri mahasiswa. Meskipun kegiatan tersebut dinilai baik dan berjalan dengan sukses namun perlu mendapat perhatian sehingga pada kesempatan pengabdian yang akan datang perlu mendapatakan prioritas demi kelangsungan pengelolaan lembaga yang lebih baik yaitu dengan adanya klinik, agar mahasiswa lebih dapat berkonsultasi mengenai masalah yang sedang dihadapi agar bisa mendapatkan penanganan lebih privasi.

\section{KESIMPULAN}

Kesimpulan yang diperoleh melalui kegiatan pengabdian ini adalah selama ini mahasiswa mempunyai konsep yang salah mengenai pendidikan seks, ketika berbicara mengenai seks selalu dianggap tabu dan tidak sesuai dengan norma. Pengabdian mengenai pendidikan seks sebagai upaya 
pencegahan perilaku seks bebas dapat membentengi diri dan berani untuk bilang tidak terhadap ajakan ajakan seks bebas, serta pembekalan pada pasangan yang ingin menikah tentang hubungan seks yang sehat dan tepat. Pengetahuan tentang kesehatan reproduksi, penting untuk diketahui oleh remaja khususnya mahasiswa untuk menyiapkan mereka menjadi orang dewasa yang bertanggung jawab atas keputusan seksual mereka sendiri, mempersiapakan secara fisik dan mental untuk pernikahan. jika informasi yang mereka dapat tercukupi mereka tidak akan mencari sendiri sumber yang tidak kredibel. Hal yang dapat disarankan dari hasil kegiatan pengabdian ini adalah perlunya pendidikan seks di perguruan tinggi dan pengoptimalan bimbingan konseling sebagai tempat perkembangan psikologis mahasiswa ketika mahasiswa menghadapi permasalahan. Penting sekali pendampingan dan sosialisasi pendidikan seks lanjutan bagi mahasiswa agar mereka mengetahui, memahami dampak yang terjadi dari perilaku seks bebas agar mereka dapat lebih berhati-hati dalam bergaul dan berhubungan dengan lawan jenis. Serta optimalnya lembaga konseling kampus sebagai media konsultasi bagi perkembangan psikologi mahasiswa.

\section{DAFTAR PUSTAKA}

Bertens, K. (2002). Aborsi sebagai Masalah etika. Gramedia Widiasarana Indonesia.

Mustari, M., \& Rahman, M. T. (2012). Pengantar Metode Penelitian. Laksbang Pressindo.

Nurlaeli, H. (2020). Pentingnya pendidikan kesehatan reproduksi dan seksualitas pada remaja santri putri Pondok Pesantren Watu Ringkel Darussalam-Karangpucung. Wijayakusuma Prosiding Seminar NasionaL, 1(1), 204-215.

Prasasti, S. (2017). Kenakalan remaja dan faktor penyebabnya. Prosiding Seminar Nasional Bimbingan Dan Konseling, 1(1), 28-45.

Pristiwanti, D. O., \& ilmiah ini berisi tentang Pergaulan, K. (2013). Pergaulan Bebas Pada Remaja di Era Globalisasi. Universitas Negeri Semarang.

Purnama, Y. (2020). Faktor Penyebab Seks Bebas Pada Remaja. Syntax Literate; Jurnal IImiah Indonesia, 5(2), 156-163.

Saifulloh, M. (2011). Aborsi dan resikonya bagi perempuan (dalam pandangan hukum Islam). JURNAL SOSIAL HUMANIORA (JSH), 4(1), 13-25.

Saputro, K. Z. (2018). Memahami ciri dan tugas perkembangan masa remaja. Aplikasia: Jurnal Aplikasi IImu-IImu Agama, 17(1), 25-32.

Setya, F. L. (2019). Pendidikan Seks Dalam Keluarga Bagi Anak di Kota Malang. SKRIPSI Jurusan Sosiologi-Fakultas IImu Sosial UM.

Suryoputro, A., Ford, N. J., \& Shaluhiyah, Z. (2006). Faktor-faktor yang mempengaruhi perilaku seksual remaja di jawa tengah: Implikasinya terhadap kebijakan dan layanan kesehatan seksual dan reproduksi. Makara Kesehatan, 10(1), 29-40.

Tari, E., \& Tafonao, T. (2019). Tinjauan Teologis-Sosiologis terhadap Pergaulan Bebas Remaja. DUNAMIS: Jurnal Teologi Dan Pendidikan Kristiani, 3(2), 199-211.

Wiradimadja, A. (2020). Parenting Education: Building Characters and Holding in Millennial Mental Problems. 145-149. https://doi.org/10.2991/assehr.k.200214.025

Zalbawi, S. (2002). Masalah Aborsi di Kalangan Remaja. Media Penelitian Dan Pengembangan Kesehatan, 12(3), 160266. 